\title{
HANNOVER RADIOCARBON MEASUREMENTS I
}

IMMO WENDT, HEINRICH SCHNEEKLOTH and ENNO BUDDE

\author{
Niedersächsisches Landesamt für Bodenforschung, Hannover
}

The following list covers the measurements in our institute until the end of 1960.

After pretreatment with $\mathrm{HCl}$ and $\mathrm{NaOH}$ the samples are converted into acetylene using the $\mathrm{CO}_{2} \rightarrow \mathrm{Li}_{2} \mathrm{C}_{2}$ reaction. The efficiency of the conversion $\mathrm{CO}_{2} \rightarrow \mathrm{C}_{2} \mathrm{H}_{2}$ always varies between $95 \%$ and $98 \%$. The acetylene is measured at a temperature-corrected pressure of $750 \mathrm{~mm}$ in a $3-\mathrm{L}$ copper counting tube. The background counting rate amounts to 19,9 counts/min and the net counting rate for recent wood to 33.0 counts $/ \mathrm{min}$. Each sample is measured 30 days after preparation for the first time and after another 20 to 30 days for the second time. For each sample the plateau of the counting gas is checked by means of an external $\mathrm{Co}^{60}$ source. It ranges from $4900 \mathrm{v}$ to $5400 \mathrm{v}$ and the slope is ca. $1 \% / 100 \mathrm{v}$. The $50 \%$-v (i.e. the voltage producing a counting rate that makes up exactly $50 \%$ of the plateau counting rate), the absolute counting rate at the plateau with external $\mathrm{Co}^{60}$ source and the coincidence counting rate all serve as controlling factors. With every measurement the sample is counted at a voltage of $5200 \mathrm{v}$ for 12 to $14 \mathrm{hr}$ and for control purposes, at a voltage of $5000 \mathrm{v}$ for ca. five hr. For each sample the average of several individual measurements is taken by multiplying each single result by a weight-factor derived from the statistical errors of sample count, background count, and standard count. The standard applied has been adapted to the recent standard of Heidelberg by means of the enriched reference standard prepared by $\mathrm{H}$. Münnich. The quoted limits of error have been calculated from the statistical errors of the measurements of sample, background, and standard.

Some of the results have been corrected according to the $\mathrm{C}^{12} / \mathrm{C}^{13}$-ratio. As far as such determinations have been carried out, the $\sigma$-values indicated refer to Solnhofen limestone. The $\mathrm{C}^{12} / \mathrm{C}^{13}$-measurements have been carried out in our laboratory by Paul Nitsch with a $\mathrm{CH} 4$ mass spectrometer of Atlas.

Abbreviations in the following text:

NLfB $=$ Niedersächsisches Landesamt für Bodenforschung, Hannover (Germany)

BfB = Bundesanstalt für Bodenforschung, Hannover (Germany)

\section{SAMPLE DESCRIPTIONS}

\section{GEOLOGIC SAMPLES}

\section{A. Germany}

Hv-15. Rieda, Niedersachsen

$1550 \pm 80$

Oak wood from gravel pit Rieda ( $52^{\circ} 53^{\prime} 25^{\prime \prime}$ N Lat, $9^{\circ} 10^{\prime} 57^{\prime \prime}$ E Long), $6 \mathrm{~m}$ depth, from an ancient embankment of the Weser River, overlain by Holocene floodplain sediments. Coll. 1960 and subm. by Konrad Richter NLfB. Comment: dates floodplain sediments of the Weser River. 
Wood from weir dam excavation Landesbergen $\left(52^{\circ} 34^{\prime} 32^{\prime \prime} \mathrm{N}\right.$ Lat, $9^{\circ}$ $06^{\prime} 45^{\prime \prime}$ E Long), $4.5 \mathrm{~m}$ depth, overlain by fluviatile silt and loamy sand. Coll. 1959 and subm. by Gerd Lüttig, NLfB. Comment: see Hv-15 and cf. Lüttig, $1960)$.

\section{Hahnenmoor series, Niedersachsen}

Pinus wood from a surface digging from the raised bog Hahnenmoor $\left(52^{\circ}\right.$ $39^{\prime} 32^{\prime \prime} \mathrm{N}$ Lat, $7^{\circ} 39^{\prime} 37^{\prime \prime} \mathrm{E}$ Long). The profile shows $3 \mathrm{~m}$ Sphagnum peat overlying mineral soil with a recurrence horizon at 80 to $100 \mathrm{~cm}$ below surface (a recurrence horizon $=$ contact plane between underlying dark, much decomposed and overlying light, slightly decomposed Sphagnum peat). Coll. 1956 and subm. by H. D. Lang, NLfB.

\section{Hv-8. Hahnenmoor I}

$4650 \pm 350$

Wood from bog base, $3 \mathrm{~m}$ depth. Comment: bog base was dated by pollen by H. D. Lang (private communication) at ca. 3000 B.c. (Zone Boundary VIII/IX of Overbeck)

\section{Hv-9. Hahnenmoor II}

$3680 \pm 100$

Wood from $120 \mathrm{~cm}$ depth. Comment: pollen study by H. D. Lang suggests an age of 1500-2000 B.C.

\section{Hv-10. Hahnenmoor III}

$3300 \pm 250$

Wood from $130 \mathrm{~cm}$ depth. Comment: date was expected to be older than Hv-9. The inversion may be due to error in sample collection.

\section{Hv-11. Oberlangen, Niedersachsen}

$6820 \pm 600$

Charcoal below a podsolic soil from a digging near Oberlangen at Ems River $\left(52^{\circ} 50^{\prime} 00^{\prime \prime} \mathrm{N}\right.$ Lat, $7^{\circ} 13^{\prime} 22^{\prime \prime}$ E Long), from 50 to $65 \mathrm{~cm}$ below surface. Coll. 1958 and subm. by Rudolf Lüders, NLfB. Comment: dates maximum age of podsolization.

\section{Hohes Moor series, Niedersachsen}

Peat samples from borings and surface diggings from the raised bog Hohes Moor near Rotenburg. Measurements date characteristic features of the pollen diagram, bog growth, and younger eolian sand sedimentation. Coll. 1959 and subm. by Heinrich Schneekloth. An extensive botanical, palynologic, and chemical study of Hohes Moor will be published by Schneekloth (1962).

Hv-74. Hohes Moor A, 48 to $52 \mathrm{~cm}$

$$
1740 \pm 100
$$

Peat from Section A $\left(53^{\circ} 11^{\prime} 31^{\prime \prime} \mathrm{N}\right.$ Lat, $9^{\circ} 26^{\prime} 17^{\prime \prime}$ E Long), 48 to 52 $\mathrm{cm}$ depth. Comment: dates the first important rise of Carpinus pollen. Difference of some $100 \mathrm{yr}$ is evident in comparison to the study by Aletsee (1958).

\section{Hv-42. Hohes Moor A, 90 to $95 \mathrm{~cm}$}

$$
1900 \pm 100
$$

Peat from Section A, 90 to $95 \mathrm{~cm}$ depth, immediately above the recurrence horizon. Comment: date does not conflict with the concept of Overbeck et al. 
(1957) as to the ages of the recurrence horizons in Gifhorn Moor and Hellwege Moor.

Hv-124. Hohes Moor A, $250 \mathrm{~cm}$

$4640 \pm 100$

Peat from Section A, $250 \mathrm{~cm}$ depth. Comment: dates the beginning fall of Ulmus pollen. Peat was correlated by pollen with boundary of Zones VIII/ IX of Overbeck. See Hv-8 (4650 \pm 350 , this date list).

Hv-43. Hohes Moor A, $450 \mathrm{~cm}$

$8630 \pm 150$

Peat from Section A, $450 \mathrm{~cm}$ depth. Comment: dates the change from soligenous to ombrogenous bog growth, which was determined by chemical means at ca. $430 \mathrm{~cm}$ depth.

Hv-44. Hohes Moor 83

$9750 \pm 160$

Peat from Section 83 (53 $53^{\circ} 11^{\prime} 41^{\prime \prime}$ N Lat, $9^{\circ} 26^{\prime} 46^{\prime \prime} \mathrm{E}$ Long), at the base of the bog. Comment: dates beginning of bog growth in the peripheral part of Hohes Moor. In its center Late-glacial pollen spectra were found at the hase.

Hv-45. Hohes Moor C

$1250 \pm 80$

Peat from Section C (53 $11^{\prime} 50^{\prime \prime}$ N Lat, $9^{\circ} 26^{\prime} 12^{\prime \prime}$ E Long), immediately below an eolian sand layer. Comment: eolian sand sedimentation was expected to correlate with increasing farming in the early Middle Ages.

Hv-46. Hohes Moor D

$5310 \pm 110$

Peat from Section D (53 $11^{\prime} 42^{\prime \prime}$ N Lat, $9^{\circ} 25^{\prime} 47^{\prime \prime}$ E Long), immediately below an eolian sand layer. Comment: age was expected to be similar to Hv-45.

\section{Stade series, Niedersachsen}

Peat from borings from the Stade marshy area at the mouth of Elbe River. Coll. 1959 and subm. by J. H. Benzler, NLfB. Samples date various phases of flooding by the North Sea. See Schneekloth and Wendt (1962).

\section{Hv-26. Stade I, 50 to $56 \mathrm{~cm}$}

$2680 \pm 90$

Phragmites peat from Section I ( $53^{\circ} 36^{\prime} 51^{\prime \prime}$ N Lat, $9^{\circ} 28^{\prime} 08^{\prime \prime}$ E Long), from 50 to $56 \mathrm{~cm}$ depth, overlain and underlain by marine silty clay.

Hv-27. Stade I, $330 \mathrm{~cm}$

$4200 \pm 90$

Alder forest peat from Section I (same locality as Hv-26) from $330 \mathrm{~cm}$ depth, overlain and underlain by marine silty clay. Comment: dates do not conflict with pollen dating by Heinrich Schneekloth. (Zones IX and X of Overbeck)

Hv-28. Stade II

$$
3036 \pm 90
$$

Peat from Section II ( $53^{\circ} 36^{\prime} 51^{\prime \prime}$ N Lat, $9^{\circ} 29^{\prime} 13^{\prime \prime}$ E Long), from 130 to $150 \mathrm{~cm}$ depth, overlain and underlain by marine silty clay. Comment: date seems to be reasonable. 
Hv-30. Stade III

$4840 \pm 100$

Peat from Section III ( $53^{\circ} 36^{\prime} 40^{\prime \prime}$ N Lat, $9^{\circ} 29^{\prime} 03^{\prime \prime}$ E Long), from 475 to $505 \mathrm{~cm}$ depth, overlain and underlain by marine silty clay. Comment: date seems to be reasonable.

\section{Twixlum series, Niedersachsen}

Peat from boring from the Twixlum marshy area at the mouth of the Ems River $\left(53^{\circ} 23^{\prime} 12^{\prime \prime} \mathrm{N}\right.$ Lat, $7^{\circ} 07^{\prime} 45^{\prime \prime} \mathrm{E}$ Long). The profile shows $50 \mathrm{~cm}$ of fen peat, overlain by $50 \mathrm{~cm}$ of marine silty clay and underlain by marine silty clay. Coll. 1959 and subm. by Heinz Voigt, NLfB. Samples date flooding by the North Sea.

\section{Hv-37. Twixlum I}

$$
1650 \pm 100
$$

Peat from 50 to $60 \mathrm{~cm}$ depth, at top of layer.

\section{Hv-38. Twixlum II}

$1700 \pm 100$

Peat from 85 to $95 \mathrm{~cm}$ depth. Comment: difference in age between $\mathrm{Hv}-37$ and $\mathrm{Hv}-38$ was expected to be greater.

\section{Neermoor series, Niedersachsen}

Peat from Onken gravel pit near Neermoor $\left(53^{\circ} 18^{\prime} 27^{\prime \prime} \mathrm{N}\right.$ Lat, $7^{\circ} 25^{\prime}$ 03" E Long). Profile shows $180 \mathrm{~cm}$ of peat overlain by $40 \mathrm{~cm}$ of Holocene marine silty clay and underlain by Pleistocene sand. Coll. 1959 and subm. by Heinz Voigt. Samples date bog growth and its flooding by the North Sea. See Schneekloth and Wendt (1962).

\section{Hv-39. Neermoor I}

$$
2930 \pm 70
$$

Sphagnum peat from 41 to $55 \mathrm{~cm}$ depth.

Hv-40. Neermoor II

$$
\mathbf{3 0 7 5} \pm \mathbf{1 0 0}
$$

Sphagnum peat from $60 \mathrm{~cm}$ depth.

\section{Hv-41. Neermoor III}

$5280 \pm 100$

Carex-Phragmites peat from 210 to $220 \mathrm{~cm}$ depth. Comment: profile was correlated by pollen with the Zones VIII to $\mathrm{X}$ of Overbeck. $\mathrm{C}^{14}$ dates are reasonable.

\section{Loxstedt series, Niedersachsen}

Peat from borings from the marshy area from the mouth of Weser River. Coll. 1959 and subm. by H. D. Lang. Samples date sediments of the North Sea.

\section{Hv-52. Loxstedt 58}

$$
1800 \pm 80
$$

Peat from Section 58 ( $53^{\circ} 25^{\prime} 51^{\prime \prime} \mathrm{N}$ Lat, $8^{\circ} 33^{\prime} 21^{\prime \prime}$ E Long), from 82 to $87 \mathrm{~cm}$ depth. Profile shows a $7-\mathrm{cm}$ peat layer overlain and underlain by marine silty clay.

\section{Hv-53. Loxstedt 108}

$$
\mathbf{2 7 5 0} \pm \mathbf{8 0}
$$

Peat from Section 108 (53 $28^{\prime} 31^{\prime \prime}$ N Lat, $8^{\circ} 34^{\prime} 15^{\prime \prime}$ E Long), from 113 to $118 \mathrm{~cm}$ depth. Profile shows a $60-\mathrm{cm}$ peat layer overlain and underlain by marine silty clay. 
Hv-53a. Loxstedt 108

Same samples as Hv-53; humic-acid fraction.

\section{Hv-54. Hagen, Niedersachsen \\ $3500 \pm 110$}

Peat from a boring in the marshy area at the mouth of Weser River $\left(53^{\circ}\right.$ $22^{\prime} 10^{\prime \prime} \mathrm{N}$ Lat, $8^{\circ} 30^{\prime} 58^{\prime \prime} \mathrm{E}$ Long), from 350 to $370 \mathrm{~cm}$ depth, overlain by marine silty clay. Coll. 1959 and subm. by H. D. Lang. Comment: dates the flooding of the North Sea in this area. Date is reasonable.

\section{Hv-61. Navigation channel Wilhelmshaven}

Wood from boring in the Jade River navigation channel near Wilhelmshaven $\left(53^{\circ} 33^{\prime} 35^{\prime \prime} \mathrm{N}\right.$ Lat, $8^{\circ} 10^{\prime} 15^{\prime \prime} \mathrm{E}$ Long), from 20 to $40 \mathrm{~m}$ below the bottom of the sea. Coll. 1957 by Ferdinand Bohlmann, Oldenburg; subm. by Konrad Richter. Comment: dates North Sea sediments in the mouth of Jade River.

\section{Nordenham T 9a series, Niedersachsen}

Peat from boring in the marshy area of the mouth of Weser River $\left(53^{\circ}\right.$ $26^{\prime} 30^{\prime \prime} \mathrm{N}$ Lat, $8^{\circ} 22^{\prime} 00^{\prime \prime} \mathrm{E}$ Long). Profile shows several peat layers overlain and underlain by marine silty clay. Coll. 1959 and subm. by Werner Müller, NLfB. Samples date different phases of flooding by the North Sea. See Schneekloth and Wendt (1962).

Hv-97. Nordenham T 9a, 110 to $115 \mathrm{~cm}$ $2730 \pm 100$

Raised bog peat from Section $\mathrm{T} 9 \mathrm{a}$.

Hv-98. Nordenham T 9a, 135 to $140 \mathrm{~cm}$ $2870 \pm 100$

Phragmites-Carex peat from Section T 9a.

Hv-99. Nordenham T 9a, 330 to $340 \mathrm{~cm} \quad 3900 \pm 120$ Peat; like Hv-98.

Hv-100. Nordenham T 9a, 370 to $380 \mathrm{~cm} \quad 4380 \pm 120$

Peat; like Hv-98. Comment: pollen study suggested a greater age.

\section{Nordenham T 9c series, Niedersachsen}

Peat from boring ca. $100 \mathrm{~m}$ away from the Nordenham T 9a boring. Coll. 1959 and subm. by Werner Müller. Samples date different phases of flooding by the North Sea. See Schneekloth and Wendt (1962).

Hv-101. Nordenham T 9c, 630 to $640 \mathrm{~cm}$ $5150 \pm 120$

Phragmites peat from Section T 9c.

Hv-102. Nordenham T 9c, 665 to $670 \mathrm{~cm}$ Phragmites-Carex peat from Section T 9c.

$5350 \pm 130$

Hv-103. Nordenham T 9c, 958 to $987 \mathrm{~cm}$ Clayey fen peat from Section T 9c.

$6200 \pm 175$ 
Hv-104. Nordenham T 9c, 1062 to $1070 \mathrm{~cm}$

$6660 \pm 120$

Alnus forest peat from Section T 9c, underlain by Pleistocene sand. Comment: dates are reasonable.

\section{Elsfleth series, Niedersachsen}

Peat from a boring in the marshy area at mouth of Weser River near Elsfleth $\left(53^{\circ} 13^{\prime} 57^{\prime \prime} \mathrm{N}\right.$ Lat, $8^{\circ} 27^{\prime} 20^{\prime \prime} \mathrm{E}$ Long). Profile shows several peat layers overlain and underlain by marine silty clay. Coll. 1959 and subm. by Werner Müller. Samples date different phases of flooding by the North Sea. See Schneekloth and Wendt (1962).

Hv-105. Elsfleth T 19

$2890 \pm 110$

Wood from Section T 19, 215 to $250 \mathrm{~cm}$ depth.

Hv-106. Elsfleth T 18, 290 to $300 \mathrm{~cm}$ $3200 \pm 140$

Clayey fen peat from Section T 18.

Hv-107. Elsfleth T 18, 370 to $380 \mathrm{~cm}$

$3710 \pm 140$

Clayey fen peat from Section T 18.

Hv-108. Elsfleth T 18, 470 to $480 \mathrm{~cm}$

$3940 \pm 110$

Fen peat from Section T 18.

Hv-109. Elsfleth T 18, 550 to $560 \mathrm{~cm}$

$4680 \pm 150$

Clayey fen peat from Section T 18.

Hv-110. Elsfleth T 18, 690 to $700 \mathrm{~cm}$

$4870 \pm 130$

Fen peat from Section $\mathrm{T} 18$.

Hv-111. Elsfleth T 18, 850 to $900 \mathrm{~cm}$

$$
6050 \pm 140
$$

Alnus forest peat from Section T 18, underlain by Pleistocene sand.

General comment: dates are reasonable.

Hv-12. Husarik

\section{B. Iceland}

Charcoal from a digging near Husarik port $\left(66^{\circ} 2^{\prime} 50^{\prime \prime} \mathrm{N}\right.$ Lat, $17^{\circ} 21^{\prime}$ $00^{\prime \prime}$ W Long), from the Kjökkemödding layer overlain by $2 \mathrm{~m}$ of eolian sand. Coll. 1958 and subm. by Konrad Richter. Comment: dates a landslide.

\section{Hv-13. Stakkahlihd I}

$1850 \pm 100$

Wood from a peat digging near Stakkahlihd village at Lodmundarfjord $\left(65^{\circ} 22^{\prime} 15^{\prime \prime} \mathrm{N}\right.$ Lat, $13^{\circ} 52^{\prime} 20^{\prime \prime} \mathrm{W}$ Long), from the base of a bog underlain by the debris of a landslide. Coll. 1958 and subm. by Konrad Richter. Comment: dates a landslide. Date does not conflict with pollen dating by Heinrich Schneekloth (unpub.).

Hv-14. Stakkahlihd II $2100 \pm 100$

Peat from the same locality and depth as Hv-13. Comment: was expected to be synchronous with $\mathrm{Hv}-13$. 


\section{ARCHEOLOGIC SAMPLES}

\section{A. Germany}

\section{Hv-24. Hemmingen, Niedersachsen}

Wood from Rehren gravel pit near Hannover $\left(52^{\circ} 19^{\prime} 10^{\prime \prime} \mathrm{N}\right.$ Lat, $9^{\circ} 45^{\prime}$ $32^{\prime \prime}$ E Long), from (possibly) $6 \mathrm{~m}$ depth. Coll. 1954 and subm. by Landesmus, Hannover. Comment: dates a fragment of a wooden paddle or spade.

\section{Hv-55. Dümmersee Canoe, Niedersachsen}

$4040 \pm 100$

Wood from a digging near Dümmersee $\left(52^{\circ} 28^{\prime} 50^{\prime \prime} \mathrm{N}\right.$ Lat, $8^{\circ} 17^{\prime} 10^{\prime \prime}$ E Long), from ca. $1 \mathrm{~m}$ depth. Coll. 1959 and subm. by Konrad Richter. Comment: dates a canoe (?) above a Mesolithic layer.

\section{Hv-56. Verden, Niedersachsen}

$1000 \pm 80$

Wood from the sandy filling of a circular rampart in Verden $\left(52^{\circ} 54^{\prime} 50^{\prime \prime}\right.$ $N$ Lat, $9^{\circ} 14^{\prime} 10^{\prime \prime}$ E Long). Coll. and subm. by Detlev Schünemann, Verden. Comment: dates the rampart which was expected to belong to the period of Heinrich I, German king (A.D. 919-936). See Schünemann (1960).

\section{Hv-58. Xanten I, Nordrhein-Westfalen $1975 \pm 100$}

Oak wood from a levelled building of Roman Age $\left(51^{\circ} 39^{\prime} 46^{\prime \prime} \mathrm{N}\right.$ Lat, $6^{\circ} 26^{\prime} 43^{\prime \prime}$ E Long), from ca. $2.1 \mathrm{~m}$ depth below floodplain sediment. Coll. 1959 and subm. by Wilhelm Wolff, Geol. Landesamt Krefeld. Comment: age of the settlement as expected.

\section{Hv-59. Xanten II, Nordrhein-Westfalen}

$1740 \pm 80$

Pine wood from the bottom casing of a small lime pit $\left(51^{\circ} 40^{\prime} 02^{\prime \prime} \mathrm{N}\right.$ Lat, $6^{\circ} 26^{\prime} 28^{\prime \prime} \mathrm{E}$ Long), from ca. $1.7 \mathrm{~m}$ depth below excavation of Roman-Age buildings. Coll. 1959 and subm. by Wilhelm Wolff. Comment: dates the lime pit.

\section{Hv-83. Kelheim, Bayern}

$1000 \pm 90$

Charcoal from a presumed pile from the wall of a gravel pit $\left(48^{\circ} 58^{\prime} 10^{\prime \prime}\right.$ $\mathrm{N}$ Lat, $11^{\circ} 53^{\prime} 50^{\prime \prime}$ E Long), from 90 to $120 \mathrm{~cm}$ depth. Coll. 1959 and subm. by Friedrich Kohl, Geol. Landesamt München. Comment: dates the charcoal pile.

\section{B. Bolivia}

\section{Kalasya series, Tiahuanacu}

Charcoal from the temple field Kalasya ( $16^{\circ} 33^{\prime} \mathrm{S}$ Lat, $68^{\circ} 41^{\prime}$ W Long). Coll. 1959 and subm. by Hannfrit Putzer, BfB.

\section{Hv-17. Kalasya, $50 \mathrm{~cm}$}

$$
\mathbf{2 4 0} \pm \mathbf{8 0}
$$

Charcoal from $50 \mathrm{~cm}$ depth. Comment: sample was later proved not to belong to the culture layer.

Hv-18. Kalasya, $175 \mathrm{~cm}$

Charcoal from $175 \mathrm{~cm}$ depth.

$1630 \pm 130$ 
Hv-19. Kalasya, $180 \mathrm{~cm}$

$1645 \pm 80$

Charcoal from $180 \mathrm{~cm}$ depth. Comment: dates of $\mathrm{Hv}-18$ and $\mathrm{Hv} \cdot 19$ are reasonable.

\section{Hv-87. Buena Vista Mine}

Wood from the Cangalli conglomerate from the Buena Vista mine near Rio Tipuani $\left(15^{\circ} 35^{\prime} \mathrm{S}\right.$ Lat, $68^{\circ} 10^{\prime} \mathrm{W}$ Long). Coll. 1959 and subm. by Hans Freydanck, BfB.

\section{Hv-114. Icla-Chullpamoko, $140 \mathrm{~cm}$}

$850 \pm 90$

Charcoal and bone from $140 \mathrm{~cm}$ depth from a post-Tiahuanacu pottery layer ( $19^{\circ} 20^{\prime} \mathrm{S}$ Lat, $64^{\circ} 48^{\prime} \mathrm{W}$ Long). Coll. 1958 and subm. by H. D. Disselhoff and H. Walter, Ethnol. Mus., Berlin.

\section{Hv-115. Icla-Chullpamoko, $270 \mathrm{~cm}$}

$1000 \pm 170$

Charcoal from $270 \mathrm{~cm}$ depth from same locality as Hv-114. Coll. 1958 and subm. by H. D. Disselhoff and H. Walter Ethnol.

\section{Hv-116. Cliza-Chullpapata}

$1850 \pm 90$

Carbonized seed (Schinus molle) from Prace-Tiahuanacu settlement $\left(17^{\circ}\right.$ $35^{\prime} \mathrm{S}$ Lat, $65^{\circ} 55^{\prime} \mathrm{W}$ Long), from $40 \mathrm{~cm}$ depth. Coll. 1958 and subm. by H. D. Disselhoff and H. Walter. Comment: seed found together with pottery corresponding to Rydens pottery from Chullpa Pampa (Grasso, 1952; 1955). Prace-Tiahuanacu age; see Crane and Griffin (1959, p. 192), sample M-510, $1680 \pm 300$.

\section{Hv-121. Huancarani}

$$
2750 \pm 100
$$

Charcoal from excavation Huancarani ( $17^{\circ} 12^{\prime} \mathrm{S}$ Lat, $67^{\circ} 55^{\prime} \mathrm{W}$ Long), from 150 to $170 \mathrm{~cm}$ depth. Coll. 1958 and subm. by H. D. Disselhoff and H. Walter. Comment: the excavated mound contained bone tools, simple pottery (ollas), some stone tools, and many guanaco and deer bones. Findings are very similar to those of younger Ongamira layers (Cordoba, Argentine). See Disselhoff 1960; Menghin and Gonzales, 1954.

\section{CROSS-CHECK SAMPLE}

\section{Hv-63. St. Walburgkerk}

Oak wood from a church at Groningen $\left(53^{\circ} 12^{\prime} \mathrm{N}\right.$ Lat, $6^{\circ} 36^{\prime} \mathrm{E}$ Long $)$, Netherlands. Subm. by Hl. de Vries, University of Groningen. Comment: $\delta=$ $-23 \%$. Wood of the same origin has been dated by several others (see list in U-69, Olsson, 1959, p. 100).

Date lists:

\section{ReFerences}

Michigan IV Crane and Griffin, 1959

Uppsala I Olsson, 1959

Aletsee, L., 1958, Über einige Korrekturen an der Zeitstellung der jüngeren Pollenzonen Nordwestdeutschlands (Ov. \& Schn. ix-xii): Geobot. Inst. Rübel, Zürich Veröffentl., no. 34, p. 13-18.

Crane, H. R., and Griffin, J. B., 1959, University of Michigan radiocarbon dates IV: Am. Jour. Sci. Radioc. Supp., v. 1, p. 173-198.

Disselhoff, H. D., 1960, Probleme der bolivianischen Archäologie: Internat. Cong. Americanist., 34th Wien, Ber. 
Firbas, F., 1949, Spät- und nacheiszeitliche Waldgeschichte Mitteleuropas nördl. der Alpen: Jena, Fischer Verlag, $480 \mathrm{p}$.

Grasso, I. D. E., 1952, La mas antigua cultura agricola de Bolivia: Antropol. Rev., Sao Paulo, v. 4, no. 1 .

1955, Esquema de la Arqueología Boliviana: Jour. Ethnology, v. 80, p. 192-199. ig, G., 1960, Zur Gliederung des Auelehms im Flussgebiet der Weser: Eiszeit. u. Gegenwart, v. 11, p. 39-50.

Menghin, O., and Gonzalez, A. R., 1954, Excavaciones arqueológicas en el yacimiento de Ongamira, Córdoba [Rep. Argentina]: Univ. Nac. de La Plata, Notes, v. 17 (Antropol.), no. 67, p. $213-273$.

Olsson, Ingrid, 1959, Uppsala natural radiocarbon measurements I: Am. Jour. Sci. Radioc. Supp., v. 1, p. 87-102.

Overbeck, F., Münnich, K. O., Aletsee, L. and Averdieck, F. R., 1957, Das Alter des "Grenzhorizontes" norddeutscher Hochmoore nach Radiocarbon-Datierungen: Flora, v. 145 , p. $37-71$.

Ryden, S., 1952, Chullpa pampa-a pre-Tiahuanaco archaeological site in the Cochabamba region, Bolivia: Ethnos, v. 17, p. 39-50 [Stockholm].

Schneekloth, Heinrich, 1962, Beiträge zur Kenntnis niedersächsischer Torflagerstätten, I. Das Hohe Moor bei Scheessel [Krs. Rotenburg/Hannover]: Geol. Jahrb., Beiheft v. 55. 1962, Beiträge zur Kenntnis niedersächsischer Torflagerstätten, II. Das Weisse Moor bei Kirchwalsede [Krs. Rotenburg/Hannover]: Geol. Jahrb., Beiheft v. 55 .

Schneekloth, Heinrich, and Wendt, Immo, 1962, Neuere Ergebnisse der $\mathrm{C}^{14}$-Datierungen in Niedersachsen: Geol. Jahrb., v. 80.

Schünemann, D., 1960, Die "Alte Burg" in Verden, eine frühgeschichtliche Befestigung: Die Kunde, Neue Folge, v. 11, p. 1-28.

Walter, H., 1960, Chuquisaca Fine Ware. Ein neuer keramischer Stil aus Südost-Bolivien: Internat. Cong. Americanists, 34th, Wien 1960, Ber. 